\title{
UM CONVITE À LEITURA
}

Apresentamos a edição 7 da e-Mosaicos - Revista Multidisciplinar de Ensino, Pesquisa, Extensão e Cultura do Instituto de Aplicação Fernando Rodrigues da Silveira (CApUERJ). Nesta edição, o leitor conhecerá um pouco das ações de ensino, pesquisa e extensão desenvolvidas no CAp-UERJ, por olhares e enfoques diferenciados.

O texto inicial da revista, de autoria de Christiane de Faria Pereira Arcuri, apresenta o ensino da Arte e aspectos de sua trajetória na instituição. Na sequência, num movimento que articula ensino, pesquisa e extensão, o diálogo com o ensino de fotografia no CAp, que é um diferencial desta Instituição, é apresentado por Johannes Andreas Valentin, ressaltando o quanto o trabalho com as linguagens artísticas é valorizado no CAp desde $01^{0}$ ano do Ensino Fundamental.

As experiências formativas da utilização de ambientes virtuais de aprendizagem na língua inglesa e as contribuições didático-pedagógicas são discutidas no artigo de autoria de Isabel Cristina Vollet Marson e Ademir Valdir dos Santos.

Retornando as ações desenvolvidas no CAp-UERJ, mas também em outras duas instituições públicas de ensino, as professoras Márcia Marin, Cristina Angélica Aquino de Carvalho Mascaro, Márcia Maria Baptista Maretti e Patrícia Braun apresentam a experiência inovadora do ensino colaborativo como estratégia positiva aos processos de inclusão escolar de estudantes com necessidades educacionais especiais. Ainda no diálogo com a temática Educação Especial / Educação Inclusiva, Márcia Pletsch, Mariana Corrêa Pitanga de Oliveira e Marcela Francis Costa Lima nos trazem as experiências do Observatório em Educação Especial e Inclusão Escolar, dialogando com os processos de ensino e aprendizagem e práticas curriculares a partir da implantação da Política Nacional de Educação Especial. 0 artigo seguinte e que encerra esta sessão é de autoria de Livaldo Teixeira da Silva e Bruno Miranda Neves e discute o sentido da Pedagogia e do Pedagogo na educação escolar.

Este número traz, também, a entrevista feita pela professora Gabriela Félix Brião com a professora Beatriz D’Ambrosio, pesquisadora reconhecida na área de Educação Matemática e professora titular do departamento de Matemática da Miami University.

Na sessão resenha, Vitor Nunes Caetano apresenta o livro "Ética e Vergonha na Cara", de autoria de Mário Sérgio Cortella e Clóvis de Barros Filho. Um convite à leitura!

Boas reflexões!

Andrea da Paixão Fernandes

Lúcia Facco 